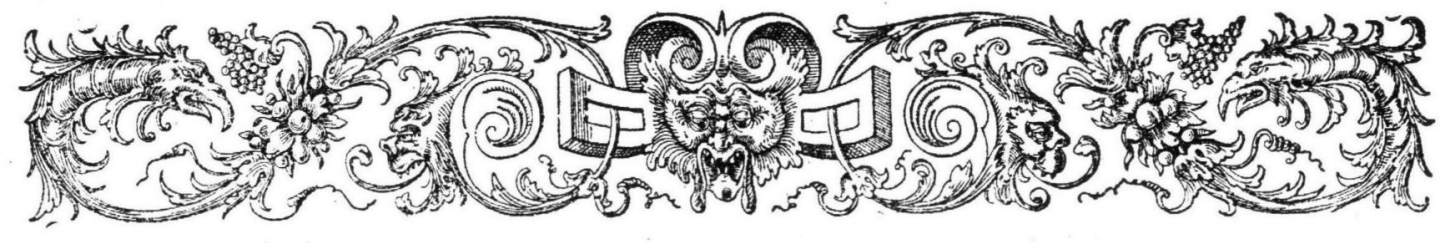

\title{
EEN WEINIG BEKENDE AANSLAG OP HET LEVEN VAN WILLEM III
}

DOOR

ED. VAN BIEMA.

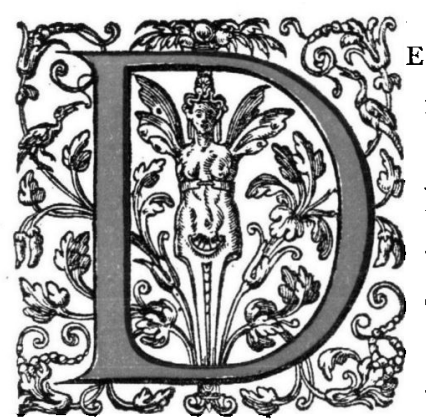

E Europeesche. Mercurius van de maand Juni I699, vermeldde het volgende:

„Den 8sten der maand wierd zekere messemaakersknecht geboortig van Lotharingen, en voormaals soldaat en deserteur geweest, die den Koning van Groot Britanje door het vergiftigen van Messen, (die hij voorgaf, vermits zijn meester gewoon was de zelven voor zijne Majesteit te maaken, gelegenheid te weeten om op des Konings tafel te doen komen) indien men hem daar een belooning voor wilde geven, gelijk hij zulks aan eenige persoonen had voorgeslagen, om 't leven wilde brengen, volgens Sententie van het Hof van Justitie met den swaarde gestraft, en zijn hoofd op de Rijswijksche weg op een staak, en het ligchaam op een rad gelegt."

Omstandige relazen van de aanslagen op het leven van WILLEM III vormden een vruchtbaar onderwerp voor zekere schrijvers van die dagen. Zoo verscheen er in het jaar 1696 te Londen een werkje dat den titel droeg van:

"An impartial history of the plots and conspiracies against the life of His Sacred Majesty King WILliaM III, contried and carried on by the pernicious councils and Devices of our professed Enemies at the Court of France, managed by their Emissaries at Home and Abroad."

Het boek scheen veel aftrek te vinden want het beleefde eene tweede uitgave in het volgende jaar 1697. 
De aanslag in de Europeesche Mercurius vermeld is van betrekkelijk geringe bekendheid en daar wij in de gelegenheid waren van de daarop betrekking hebbende stukken in de gerechtelijke archieven kennis te nemen, willen wij daaromtrent het een en ander mede deelen.

De schuldige, NICOLAS JACOT of JACQUOT, op het tijdstip zijner arrestatie messenmaker in dienst van SIMON PEzÉ, "coutelier du Roy" te 's-Gravenhage, telde omstreeks 32 jaren. Hij was geboortig van Ligne-en-Barrois in Lotharingen en beleed den Roomschen godsdienst. Zijne gevangenneming had plaats op het einde van de maand April I699. Het beroep van messenmaker oefende hij slechts tijdelijk uit; zijn eigenlijke loopbaan was die van soldaat.

Even als zoo vele beroepssoldaten uit die dagen, makte hij er zich volstrekt geen gewetenswroeging over, beurt om beurt de beide oorlogvoerende partijen, Frankrijk en Holland te dienen.

Wanneer zulks hem voordeelig voorkwam liet hij zijn Fransch regiment in den steek om over te loopen naar Hollandsche zijde.

Zoo had hij onder Franschen vlag gediend in het regement Zwitsers van den kolonel CouRT. Hij deserteerde en kwam na eenige omzwervingen in den Haag, alwaar hij werk vond bij den messenmaker des konings, PEZÉ.

$\mathrm{Na}$ tien maanden bij dien patroon gewerkt te hebben verdween hij wederom uit 's-Gravenhage.

Het schijnt dat hij toen dienst nam in het regiment van den Hertog van Holstein in de soldij der republiek en dat hij o.a. ook te Amsterdam in garnizoen gelegen heeft. Van daar werd zijn regiment naar Nieuwpoort gedirigeerd en vervolgens naar Dixmuiden, alwaar hij met de gansche bezetting door de Franschen krijgsgevangen werd genomen.

Het zij ons vergund even uit te wijden over dit punt. De Fransche Maarschalk DE VILLEROY, die geen kans zag om den Prins van VAUdEMONT in de Zuidelijke Nederlanden afbreuk te doen, zond den Graaf DE MONTAL met eenige troepen af om Dixmuiden te overmeesteren. ELLENBERG, of ook ELLENBERGER, voerde het commando over de plaats, die slecht versterkt was. $\mathrm{Na}$ eene flauwe verdediging van slechts 36 uren capituleerde hij den 28 Juli 1695 en gaf de bezetting krijgsgevangen. Generaal ELLENBERGER werd wegens deze laffe overgave voor een krijgsgerecht gedaagd, schuldig bevonden aan lafhartigheid en met den zwaarde gestraft.

Pamflet No. 14045 in de Kon. Bibl. geeft over dit vonnis nadere opheldering. Het is getiteld: „Sentence prononcée par le Grand Conseil de Guerre, Commandé du Roy d'Angleterre, tenu à Gand, depuis le 19 Octobre jusques an 4 Novembre I695."

De aanklacht was gericht tegen al de hoofdofficieren, die bevel gevoerd 
hadden over de bezetting van Dixmuiden. Het vonnis tegen den commandant Ellenberger luidde als volgt:

„JoAn Anthoine Ellenberger, cy devant Gouverneur de la ville de Dixmuyde, a été assiegé par le corps du Comte DE MONTAL le 25, de Juillet passé, a eu 8 Regimens d'Infanterie \& un Regiment de Dragons, genz tout portez à se défendre jusques au dernier, a eu bonne Artillerie, Munition, Poudre, Armes, \& Vivres en abondance, s'est rendu aux Ennemis le 28. Juillet passé, par une Capitulation toute honteuse, au grand préjudice du Roi d'Angleterre \& de ses Alliez, sans avoir attendu un assaut, sans avoir eu Brêche, ouvrage pris, \& tres-peu de monde tué, est condamné d'avoir la tête tranchée, \& ses biens dans ce Pays-cy confisquez, \& employez pour remettre le Regiment qu' il a eu."

De hoofdofficieren James Lesle, Richard Brewer, Charles Graham en LOUIS AVER, werden van hunne rangen vervallen verklaard. De overige betrokken a anvoerders werden vrijgesproken, "les recommandant à leurs maîtres comme Gens d'Honneur et de Merite."

Onder de laatsten telde men ook François Philippe Plato, Luitenant Kolonel en Commandant van het regiment Infanterie van Jonge Holstein, waarbij JACOT gediend had. De voltrekking van het vonnis aan ELLENBERGER vond plaats te Gent buiten de Antwerpsche poort op 30 November I695. Hij was 58 jaar oud, en had van gemeen soldaat af alle rangen doorloopen, zonder ooit een berisping te hebben verdiend.

Keeren wij na deze afdwaling terug tot onzen vriend JACOT, die door het slechte voorbeeld zijner superieuren wellicht werd aangezet om het Hollandsche vaandel te verlaten en zich bij de Franschen te voegen. Ten minste wij vernemen uit de stukken, dat hij dienst nam bij het Fransche regiment $Z$ witsers van Kolonel CourT. Lang bleef hij niet trouw an dit vendel, want hij deserteerde opnieuw en nam de wijk naar 's-Gravenhage.

In het voorjaar van 1697 klopte hij ten andere male aan bij zijn vroegeren meester PÉzé. Deze nam hem weêr in dienst en hij bleef onafgebroken bij hem werkzaam tot op het noodlottige oogenblik, toen hij in minder aangename aanraking kwam met den Hoofd-officier der stad 's-Gravenhage.

JACOT was getrouwd en had een kind; hij woonde met zijn gezin in bij eene kaaskoopster, die haar nering uitoefende in het huis waar de drie kazen uithingen, in het Blaeuwe Straetje in de onmiddelijke nabijheid van de Begijnstraat.

$\mathrm{Hij}$ was een der vele individuen, die in den loop der regeering van WILLEM III uit winstbejag of uit dweepzucht een aanslag beraamden op het leven van dezen Vorst.

Hier bleef het slechts bij het plan; het kwam zelfs niet tot een begin van Oud-Holland, 1908. 
uitvoering, doordien de zaak ruchtbaar werd en de justitie de hand op JACOT legde.

Door wien de justitie eene aanwijzing omtrent JACOT's misdadige bedoelingen kreeg, blijkt niet uit de stukken, doch men mag wel aannemen, dat dit geschiedde van de zijde der Fransche ambassade, tot welke onze messenmaker zich persoonlijk met het aanbod gewend had om den Koning uit den weg te ruimen.

Op 29 April werd hij op bevel van de justitie op de Voorpoort gebracht om daar nacht en dag door een dienaar bewaakt te worden. Zijne goederen werden onderzocht en al datgene wat suspitie zou kunnen geven, ten hove gedeponeerd.

Tezelfdertijd werden zijne twee kameraden, werkzaam bij PEZÉ, en de meester zelf, ieder afzonderlijk op de Voorpoort opgesloten.

Ook het huis en den inboedel van PEZÉ werden aan een nauwkeurig onderzoek onderworpen.

Het scheen dat JACOT reeds lang rondging met de gedachte om den koning te vermoorden, want hij bekende er herhaalde malen over gesproken te hebben met zijn kameraad, LAURENS VILLEMARS, geboortig uit het stadje Thuin in het land van Luik, die sedert October 1698 met hem bij PEZÉ werkte. VILLEMARS had hem altijd ernstig aangemaand dit misdadige denkbeeld op te geven. De verdachte werd gedurende den loop der zaak aan twee verhooren onderworpen, waarvan wij de hoofdtrekken zullen mededeelen.

Deze verhooren hadden waarschijnlijk plaats op 29 en 30 April.

Op een dag toen JACOT bezig was met het smeden van messen, en zijn patroon daarop zijn merk zette, zeide hij tot zijn kameraad VILlemars, dat is een goed diep merk; alle messen des konings dragen dit merk. Het is heel gevaarlijk, de koning van Frankrijk zou zulks niet gedoogen, omdat men er zoo gemakkelijk vergif in kan doen. De getuigenis zijner kamaraden en van zijn patroon luidden het tegendeel van ongunstig voor den verdachte. Men kon niets kwaads te zijnen laste zeggen en men roemde hem als een ijverig werkman, die trouw ter mis ging in de kerk der Fransche Ambassade en zich nooit in afkeurende termen over den koning van Engeland had uitgelaten. SimoN PEzÉ was even positief in zijn gunstig oordeel, en deelde verder mede, dat hij geregeld de messen van's konings tafel kreeg om die te slijpen; wanneer er veel werk was en hij het volhandig had, belastte hij zijne knechts daarmede.

Een andere kameraad van JACOT, JEAN ChORIN, van Coromarin in Provence, die sedert den Io Juni 1698 bij PEzÉ in dienst was, kon evenzoo niet anders dan goeds van den eerste zeggen. Deze dronk niet, vloekte nooit, was geen losbol en werkte altijd zeer vlijtig.

JACOT vervoegde zich op 27 April ten huize van den Franschen Ambassadeur DE BONREPOS, waar hij den portier verzocht om den Secretaris van den Ambassadeur, den Heer DE CAMPREDON, te mogen spreken. 
Door den portier bij den Secretaris geleid, vroeg hij hem alleen te mogen spreken, daar hij hem eene hoogst gewichtige mededeeling wenschte te doen. Toen de portier op last van den Secretaris het vertrek verlaten had, vroeg JACOT of er in de Ambassade niemand was, die in dienst stond van den verdreven koning van Engeland.

Hij deelde toen den Secretaris mede, dat hij een onfeilbaar middel bezat om messen te vergiftigen, zonder dat ooit iemand zou kunnen ontrekken, dat hij op deze wijze den koning WILLEM III uit den weg zou hebben geruimd.

Toen vertelde hij den Secretaris, dat hij in dienst zijnde bij 's konings messenmaker PEzk, alwaar al de tafelmessen des vorsten gebracht werden om schoon gemaakt te worden, de gelegenheid had en het middel bezat om den koning te vergiftigen.

Monsieur DE CAMPREDON antwoordde hem daarop, dat aangezien er nu vrede tusschen de beide staten heerschte, men niet naar zulke middelen behoefde te grijpen en niet wenschte den koning uit den weg te ruimen. Hij trachtte hem van zijn voornemen af te brengen en vroeg hem hoe hij op de gedachte van een koningsmoord gekomen was, waarop JACOT hem antwoordde: Koning WiLlEM heeft wel een anderen koning onttroond.

JACOT herinnerde zich niet of hij den secretaris DE CAMPREDON geld gevraagd had voor de uitvoering van zijn plan. Wel was hij voornemens geweest een som gelds te vragen om den Haag te kunnen verlaten en zich in Brabant als messenmaker te vestigen. Hij bekende het eerst over de zaak gesproken te hebben met den koetsier van den Franschen gezant, dien hij kende omdat deze van tijd tot tijd in PEZÉ's winkel kwam om daar messen te brengen, die geslepen moesten worden.

Dit eerste gesprek met den koetsier hield hij bij het uitgaan der mis in het Fransche gezantschapsgebouw, en hij vroeg hem toen ook of er in de ambassade niemand was, die in betrekking stond tot den verdreven Engelschen koning.

De koetsier zeide toen niets met de zaak te maken te willen hebben en dat JACOT zich maar moest wenden tot den eersten secretaris.

Naderhand had de messenmaker den koetsier nog drie of vier malen over zijn plan onderhouden.

Bij het tweede verhoor beweerde hij nooit de intentie gehad te hebben, zijn plan ten uitvoer te brengen, doch dat hij slechts beoogde, door dit middel wat geld te krijgen, en dan de stad te verlaten. Niemand had hem tot de daad aangezet. Noch zijn meester, noch zijne kameraden, noch zijne vrouw, noch iemand anders ter wereld, hadden daarvan kennis gehad. Hij was de eenige schuldige, en hij werd op de gedachte gebracht, door de in den winkel gevoerde 
gesprekken over de geruchten van plannen om den koning van Engeland het leven te benemen.

Op $4 \mathrm{Mei}$ werd besloten JACOT te brengen ter scherper examen "omme van denselven te onderstaan de circumstantien van het faict en syne complices."

Op 6. Mei werd geresolveert den gevangene niet te brengen ter torture, maar alleenlijk te presenteeren de torture en sulx ad actum proximum omme syne complices ende circumstancien te weten.

De gevangene werd daarop in den kelder gebracht alwaar de folterwerktuigen stonden, ontkleed en gebonden, daar hij echter niet anders bekennen wilde, dan hij reeds bekend had, werd hij wederom naar boven geleid.

Lang behoefde hij niet te wachten op de beslissing van zijn lot.

Reeds vier dagen later werd zijn vonnis gewezen, waarbij hij ter dood werd veroordeeld.

Het vonnis luidde als volgt:

"Soo heeft het voorszeyde Hoff met rijpe deliberatie van raede doorgesien ende overwogen hebbende alle 't gene ter materie dienende is, ende heeft mogen moveren, reght doende uyt den name ende van wegen de Hoge Overheyt ende Graeffelijkheyt van Hollant, Zeelant, en Vrieslant, verclaart den gevangen begaan te hebben crimen laesae Majestatis; condemneert hem gebragt te werden ter plaetse daer men gewoont is criminele justitie te doen, ende aldaer metten swaerde te werden geexecuteert datter de doodt na volgt, ende desselfs lighaem gelegt te werden op een radt, ende thooft gestelt op een staeck; verclaert alle zyne goederen ten behoeve van de Hoge Overheyt geconfisqueert, ende condemneert hem inde costen ende mise van justitie tot tauxatie ende moderatie van de voorzeyde Hove. Gedaen in den Hage bij de Heeren ende Meesters FrederiK Sluysken Praesident, Matheus Gool, Benjamin Fagel Heere van ter Weer, Johan Munter, François Keetlaer, Paul André van der Meulen, Jacob Vallensis, Anthonis Slicher, Frederik Rosenboom ende Adriaen Pieter D'HinojosA, raets luyden van Hollant, ende gepronuncieert den VIIIe Mey XVIC negen ende 't negentich.

In kennisse van mij

ANT. VAN KUNSCHOT. I 699.

Zoo veroordeelde een rechtscollege in de $17 \mathrm{e}$ eeuw iemand ter dood, omdat hij schuldig was bevonden aan het koesteren van een misdadig voornemen terwijl aan dit voornemen een der voornaamste eischen van strafbaarheid ontbrak, namelijk het begin van uitvoering.

Iets dergelijks is heden ten dage gelukkig niet meer denkbaar.

's-Gravenhage, December 1907. 


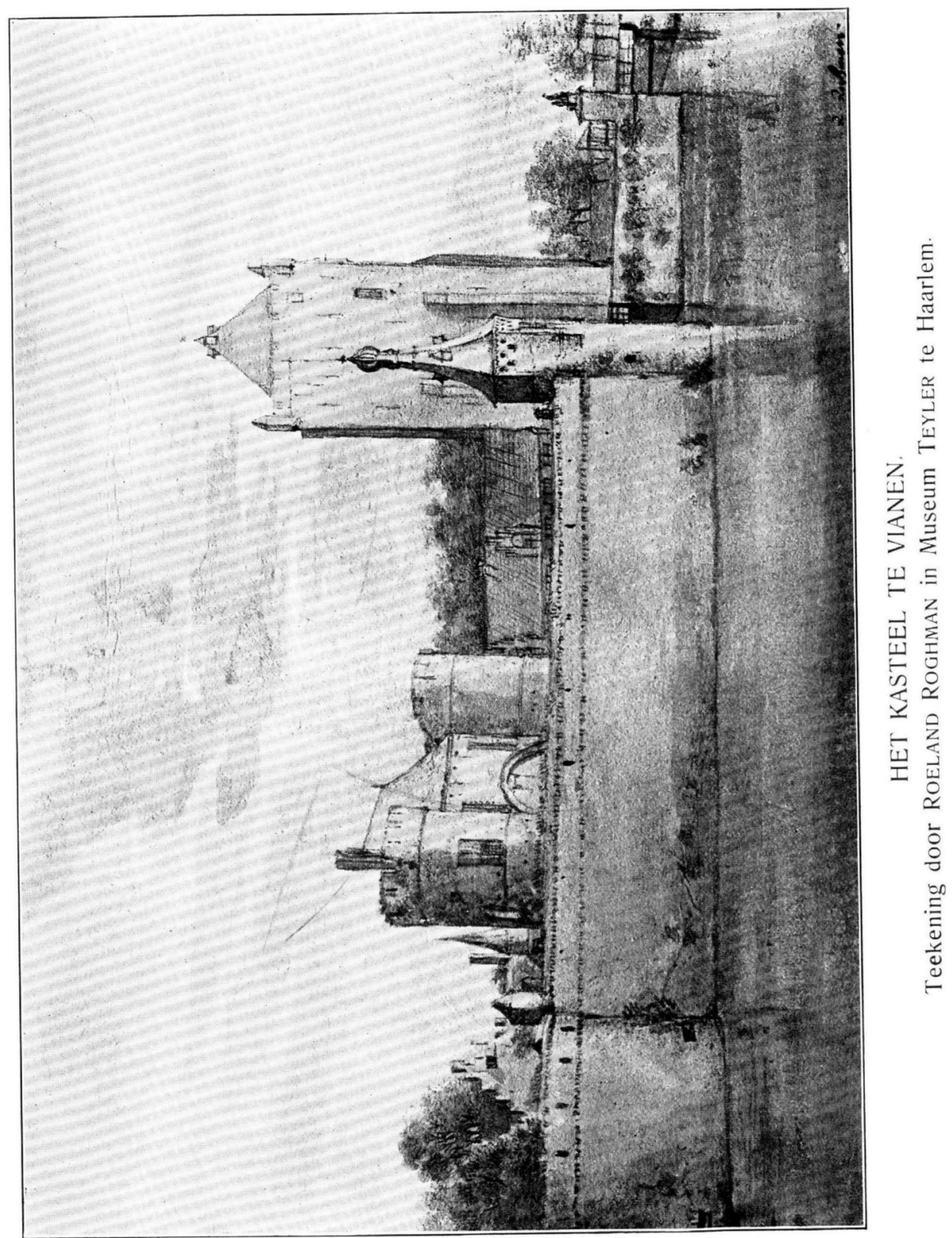





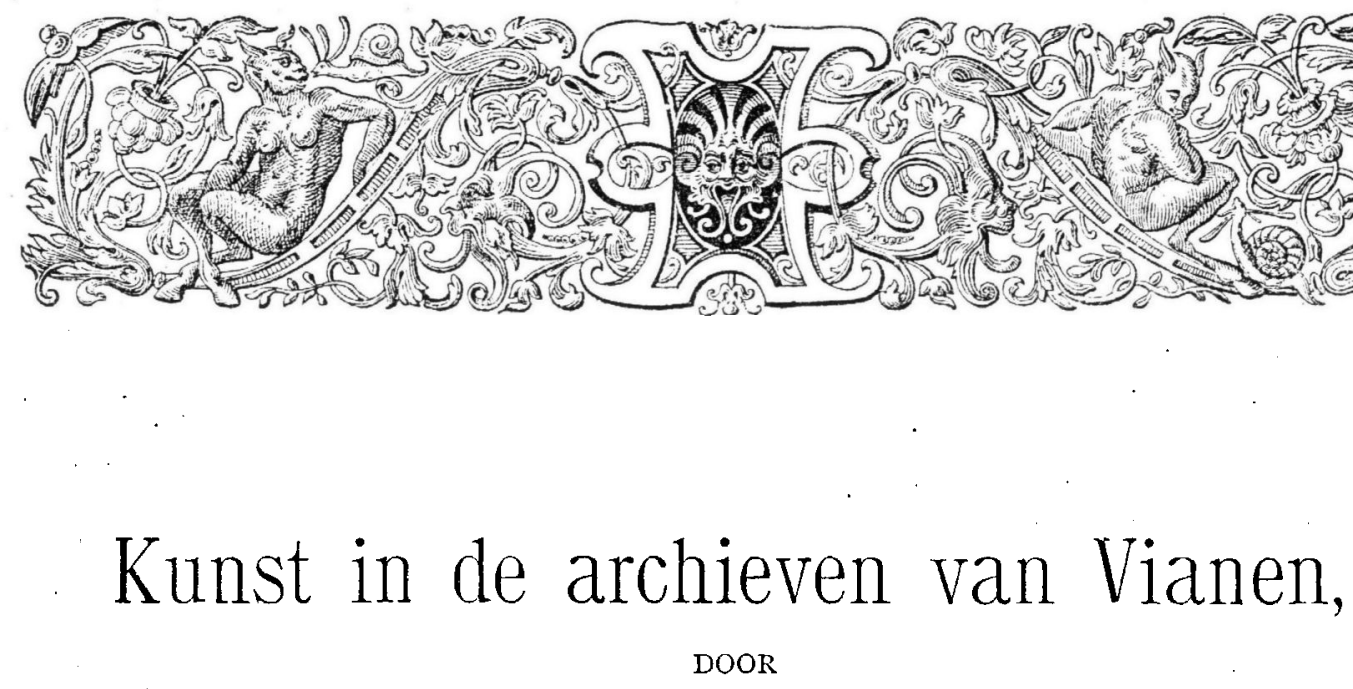

$M^{R}$ PETER VAN MEURS.

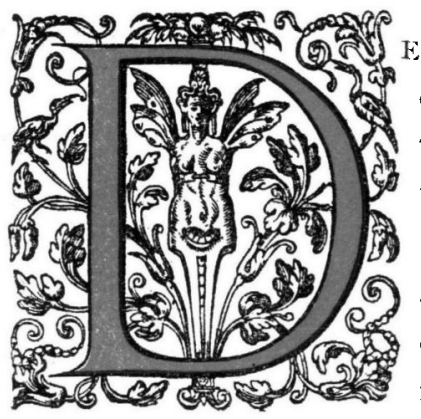

E oude archieven van Vianen bevinden zich gedeeltelijk op het raadhuis van de gemeente, t. w. de administratieve stukken, gedeeltelijk op het Algemeen Rijksarchief, t. w. de rechterlijke stukken.

Men vindt er enkele inventarissen en andere stukken onder van eenig algemeen belang, betreffende de goederen van de BREDERODE's, en eenige andere, waarin melding van schilderijen of schilders gemaakt wordt.

\section{STUKKEN BETREFFENDE DE GOEDEREN VAN DE BREDERODE'S.}

De stad Vianen met het omliggende land vormde lang het gebied van de BREUERODE's, tot het uitsterven van dit geslacht in December I684, nieuwe stijl. $\mathrm{Zij}$ bewoonden er het huis Batestein, en bezaten in het Viaansche bosch een zomerhuis Amelestein. Van zoo'n vermaard geslacht, dat zich vermaagschapte met geslachten als die van NASSAu, Solms, DoNa en tal van andere van den hoogsten Europeeschen adel, is het niet onbelangrijk, de inrichting en meubeleering van zijn woning te leeren kennen, waardoor men tevens met veel schilderijen, voorwerpen van amber, terpentijn, lakwerk, albast, kristal, schildpad, zilver, porselein, merken van linnen, enz. kennis maakt. Ik laat daarom eenige inventarissen van goederen VAN BREDERODE's volgen, met weglating alleen van 